\title{
2
}

\section{PERLINDUNGAN TERHADAP ANAK YANG BERHADAPAN DENGAN HUKUM}

\author{
Oleh: \\ Rendy H. Pratama, Sri Sulastri, \& Rudi Saprudin Darwis
}

\begin{abstract}
E-mail:
rendyhp02@gmail.com; ati.sukaati@gmail.com; rsdarwis@gmail.com
\end{abstract}

\begin{abstract}
ABSTRAK
Penyimpangan tingkah laku atau perbuatan melanggar hukum yang dilakukan anak disebabkan oleh berbagai faktor, antara lain adanya dampak negatif dari perkembangan pembangunan yang cepat, arus globalisasi dibidang komunikasi dan informasi, kemajuan ilmu pengetahuan dan teknologi serta perubahan gaya dan cara hidup sebagian orang tua, telah membawa perubahan sosial yang mendasar dalam kehidupan masyarakat yang sangat berpengaruh terhadap nilai dan perilaku anak. Hal ini dikarenakan pada usia dini, sang anak masih dalam keadaan labil dan mudah terbawa arus kehidupan masyarakat dan lingkungan sekitar yang dapat mempengaruhi pola tingkah laku anak itu sendiri. Dalam menghadapi dan menanggulangi berbagai perbuatan tingkah laku anak yang diduga melakukan suatu tindakan pidana, harus bisa dibedakan dengan kasus yang dialami oleh orang dewasa. Tidak sewajarnya anak dibawah umur mendapat penyidangan yang terlalu lama, yang dapat menjadikan trauma pada perkembangan mental anak. Menurut UU no 11 tahun 2012 pasal 91 ayat 3, setelah melakukan persidangan anak harus menjalani rehabilisasi sosial, yang bertujuan untuk memulihkan kondisi fisik dan mental anak yang tersandung kasus agar bisa kembali melaksanakan fungsi sosialnya.

Kata kunci: Penyimpangan tingkah laku; sistem peradilan anak; perkembangan mental
\end{abstract}

\section{Pendahuluan}

Anak pada dasarnya adalah manusia yang terlahir ke dunia dan masih suci. Namun sering kali, pada kenyataannya masih banyak anak yang tidak mendapatkan hak-haknya, ia tidak mendapatkan pendidikan yang layak, tidak ada yang mengasuh, tidak mendapat perawatan dan hak-hak lainnya.

Dalam implementasinya, anak merupakan sumber daya manusia bagi pembangunan suatu bangsa, penentu masa depan dan penerus generasi. Namun demikian kita sadari bahwa kondisi anak masih banyak yang memprihatinkan. Hal ini dapat dilihat bahwa belum semua anak mempunyai akta kelahiran; belum semua anak diasuh oleh orang tua, keluarga maupun orang tua asuh atau wali dengan baik; masih belum semua anak mendapatkan pendidikan yang memadai; masih belum semua anak mempunyai kesehatan optimal; masih belum semua anak-anak kelompok minoritas dan anak-anak yang berhadapan dengan hukum mendapatkan perlindungan khusus.

Sebagai salah satu unsur yang harus ada di dalam negara hukum dan demokrasi, perlindungan terhadap hak-hak asasi manusia termasuk di dalamnya perlindungan terhadap anak yang kita harapkan sebagai penentu masa depan bangsa Indonesia dan sebagai generasi penerus harus mendapatkan pengaturan yang jelas, dalam hal ini hak dalam perlindungan hukum. Hal ini perlu dilakukan, mengingat manusia sebagai makhluk ciptaan Tuhan Yang Maha Esa dianugerahi hak asasi untuk menjamin keberadaan harkat dan martabat kemuliaan dirinya sehingga HAM merupakan hak dasar yang secara kodrati melekat pada diri manusia, bersifat universal dan langgeng. Maka dari itu, 
HAM harus dilindungi, dihormati, dipertahankan, dan tidak boleh diabaikan, dikurangi, atau dirampas oleh siapapun. Untuk pelaksanaan perlindungan HAM tersebut, diperlukan adanya pengaturan di dalam hukum dasar di Indonesia. Di samping itu, sebagai anggota Perserikatan BangsaBangsa, sudah selayaknya bangsa Indonesia mengemban tanggung jawab moral dan hukum untuk menjunjung tinggi dan melaksanakan Deklarasi Universal tentang HAM.

Di samping faktor-faktor yang dapat diukur kemajuannya melalui HDI, banyak hal lain yang menyangkut kualitas anak, tetapi masih sulit diatasi dan diukur karena kesulitan data dan informasi, serta kompleksitas permasalahannya. Hal tersebut termasuk tindak kekerasan terhadap anak, diskriminasi, dan minimnya anak dalam upaya untuk mendapatkan perlindungan pada saat mereka tengah berhadapan dengan hukum Masalah lainnya adalah perdagangan anak termasuk pornografi dan pornoaksi. Demikian pula permasalahan yang menimpa perempuan dan anak di daerah konflik dan bencana, penyandang cacat, dan remaja, yang memerlukan perhatian khusus dalam rangka pemenuhan dan perlindungan atas hak-hak azasi mereka.

Persoalan lainnya ialah banyaknya hukum dan peraturan perundang-undangan yang hanya hanya sekedar ada tapi tidak ditegakan, diskriminatifdan belum peduli anak. Perangkat hukum pidana yang ada belum cukup lengkap dalam melindungi setiap individu, salah satu diantaranya adalah perlindungan terhadap anak yang sedang terjerat dan berhadapan dengan hukum.Peraturan perundang-undangan yang ada juga belum dilaksanakan secara konsekuen untuk menjamin dan melindungi hak-hakanak, termasuk memberikan perlindungan bagi anak dari tindak kekerasan, apalagi dengan mereka yang tersangkut masalah hukum. Kebutuhan tumbuh-kembang anak juga belum sepenuhnya menjadi pertimbangan utama dalam perencanaan dan pelaksanaan proses hukum. Di samping itu, partisipasi anak dalam proses perkembangan hukum juga masih rendah.

Pemahaman akan konsep kesetaraan dan dalam perlindungan anak dalam hukum masih sangat terbatas di semua kalangan, demikian pula pemahaman akan pentingnya anak sebagai generasi penerus bangsa masih harus ditingkatkan. Keterbatasan pemahaman itu juga terjadi di antara para perencana dan pelaksana pembangunan, yang selanjutnya turut memperlambat upaya-upaya pengintegrasian konsep tersebut ke dalam berbagai kebijakan, program, dan kegiatan pembangunan.

Program peningkatan perlindungan anak yang berhadapan dengan hukum dapat dilaksanakan dengan baik, apabila ada kelembagaan yang menanganinya, baik di tingkat nasional maupun daerah. Saat ini kelembagaan dan jaringan pengarusutamaan anak masih lemah. Di era desentralisasi, timbul masalah kelembagaan dan jaringan di daerah (provinsi dan kabupaten/kota), terutama yang menangani masalah-masalah anak berhadapan dengan hukum. Karena program-program pemberdayaan anak dan program perlindungan anak yang berhadapan dengan hukum merupakan program lintas bidang, maka diperlukan koordinasi di tingkat nasional dan daerah, mulai dari perencanaan hingga pelaksanaan dan evaluasi, termasuk dalam pemenuhan komitmen internasional, seperti Convention on the Elimination of All Forms of Discriminations Against Women, Beijing Platform for Action, Convention on the Rights of the Children, dan World Fit for Children. Komitmen tersebut pada dasarnya mendorong semua negara agar mengintegrasikan persamaan hak dan penghapusan diskriminasi pada semua peraturan perundang-undangan, program dan kegiatan pembangunan, serta melaksanakan penegakan hukum terhadap pelanggarannya.

\section{Tidak Terlindunginya Anak yang Berhadapan dengan Hukum di Indonesia}

Negara berkewajiban melindungi anak-anak dari perlindungan hukum, baik itu pada saat itu menjalani pengadilan sampai sesudah menjalani pengadilan tersebut. Karena setiap warga negara berhak mendapatkan perlindungan dari hukum, terutama anak-anak yang masih sangat perlu dalam menjalani kasus hukum tersebut. Perlindungan anak diusahakan oleh setiap orang, orang tua, keluarga, masyarakat, pemerintah maupun Negara. Pasal 20 Undang-Undang Perlindungan Anak menentukan bahwa "Negara, pemerintah, masyarakat, keluarga, dan orang tua berkewajiban dan bertanggung jawab terhadap penyelenggaraan perlindungan anak." 
Berdasarkan Pasal 1 ayat (2) UU No. 11 Tahun 2012 tentang Sistem Peradilan Pidana Anak, yang dimaksut dengan anak yang berhadapan dengan hukum (children in conflict with the law), adalah sebagai berikut :

"Anak yang Berhadapan dengan Hukum adalah Anak yang berkonflik dengan hukum, anak yang menjadi korban tindak pidana, dan anak yang menjadi saksi tindak pidana."

Melihat kecendrungan yang ada di media saat ini, baik media cetak maupun media elektronik, jumlah tindak pidana yang dilakukan oleh anak (juvenile delinquency) semakin meningkat dan semakin beragam modusnya. Masalah delinkuensi anak ini merupakan masalah yang semakin kompleks dan perlu segera diatasi, baik oleh pemerintah maupun masyarakat. Menurut Romli Atmasasmita dalam Wagiati Soetodjo, motivasi intrinsik dan ekstrinsik dari kenakalan anak adalah sebagai berikut :

Yang termasuk motivasi intrinsik dari pada kenakalan anak-anak adalah :

- Faktor intelegentia;

- Faktor usia;

- Faktor kelamin;

- Faktor kedudukan anak dalam keluarga.

Yang termasuk motivasi ekstrinsik adalah :

- Faktor rumah tangga;

- Faktor pendidikan dan sekolah;

- Faktor pergaulan anak;

- Faktor mass media.

Berbagai faktor tersebut memungkinkan bagi anak untuk melakukan kenakalan dan kegiatan kriminal yang dapat membuat mereka terpaksa berhadapan dengan hukum dan sistem peradilan. Anak yang melakukan tindak pidana ini bisa disebut pula dengan anak yang berhadapan dengan hukum.

Terkait upaya memberikan perlindungan terhadap anak yang berhadapan dengan hukum, sistem peradilan pidana anak harus dimaknai secara luas, ia tidak hanya dimaknai hanya sekedar penanganan anak yang berhadapan dengan hukum semata. Namun sistem peradilan pidana anak harus juga dimaknai mencakup akar permasalahan (root causes) mengapa anak melakukan perbuatan pidana dan upaya pencegahannya. Lebih jauh, ruang lingkup sistem peradilan pidana anak mencakup banyak ragam dan kompleksitas isu mulai dari anak melakukan kontak pertama dengan polisi, proses peradilan, kondisi tahanan, dan reintegrasi sosial, termasuk pelaku-pelaku dalam proses tersebut. Dengan demikian, istilah sistem peradilan pidana anak merujuk pada legislasi, norma dan standar, prosedur, mekanisme dan ketentuan, institusi dan badan yang secara khusus diterapkan terhadap anak yang melakukan tindak pidana.

Selain itu, berbagai instrumen hukum nasional yang menjadi dasar penyusunan yakni UndangUndang Dasar 1945, Undang-undang No. 39 tahun 1999 tentang HAM dan Undang-undang No. 23 tahun 2002 tentang Perlindungan Anak. Dalam Undang-undang No. 23 tahun 2002 tentang Perlindungan Anak. UU No. 11 tahun 2012 tentang Sistem Peradilan Pidana Anak. :

1. Anak adalah seseorang yang belum berusia 18 (delapan belas) tahun, termasuk anak yang masih dalam kandungan;

2. Perlindungan anak adalah segala kegiatan untuk menjamin dan melindungi anak dan hak-haknya agar dapat hidup, tumbuh, berkembang, dan berpartisipasi secara optimal sesuai dengan harkat dan martabat kemanusiaan, serta mendapat perlingungan dari kekerasan dan diskriminasi.

\section{Sistem Peradilan Pidana Anak (SPPA) dengan UU No. 11 tahun 2012}

Harus diakui dari penelitian dan pengkajian yang mendalam setelah berlakunya UU No. 3 tahun 1997 tentang Pengadilan Anak hingga berlaku \pm 15 tahun bahwa Penjara bukan tempat yang 
baik bagi anak apalagi dengan usia pertanggung jawaban pidana yang terlalu rendah sehingga dengan berbagai upaya yang telah dilakukan baik melalui Advokasi Kebijakan dan pembelaan terhadap anak yang berkonflik yang dilakukan beberapa NGO / LSM dan KPAI melakukan uji materil ke Mahkamah Konstitusi sampai perjuangan ke Parlemen sehingga membuahkan hasil lahirnya UU No. 11 tahun 2012 tentang Sistem Peradilan Pidana Anak. Dalam Undang-undang yang baru akan efektif berlaku pada bulan Juli 2014 ini wajib mengutamakan pendekatan Restoratif Justice (Keadilan Restoratif) dan Diversi.

Keadilan restoratif adalah penyelesaian perkara tindak pidana dengan melibatkan pelaku, korban, keluarga pelaku/korban dan pihak lain yang terkait untuk bersama-sama mencari penyelesaian yang adil dengan menekankan pemulihan kembali pada keadaan semula dan bukan pembalasan. (Pasal 1 angka 6 UU No. 11 tahun 2012).

Sedangkan diversi adalah pengalihan penyelesaian perkara anak dari proses peradilan pidana ke porses di luar peradilan pidana. (Pasal 1 angka 7 UU No. 11 tahun 2012). Tujuan yang diharapkan dari Diversi ini adalah :

- Tercapainya perdamaian antara anak sebagai pelaku dengan korban;

- Menyelesaikan perkara Anak di luar proses peradilan;

- Menghindarkan anak dari perampasan kemerdekaan;

- Mendorong masyarakat untuk berpartisipasi;

- Menanamkan rasa tanggung jawab kepada anak.

Dalam system peradilan pidana anak yang baru ini pada setiap tingkatan diberikan waktu masing-masing 7 (tujuh) hari diwajibkan untuk mengupayakan diversi yang diberikan terhadap Penyidik, Jaksa dan Hakim. Sedangkan waktu pembahasan dalam proses Diversi tersebut diberikan waktu 30 (tiga puluh) hari pada setiap tingkatnya.

Apabila gagal atau dengan perkataan lain Diversi pada setiap tingkatan tidak berhasil dengan tenggat waktu tersebut berakhir maka proses akan tetap berjalan mulai penyidikan, penuntutan sampai proses persidangan. Untuk batas usia tanggung jawab pidana anak pada usia 12 (dua belas) tahun tetapi belum berumur 18 (delapan belas) tahun (pasal 1 angka 3 UU No. 11 tahun 2012). Penahanan terhadap anak hanya dapat dilakukan pada anak yang telah berumur 14 (empat belas) tahun dan diduga melakukan tindak pidana dengan ancaman pidana penjara 7 (tujuh) tahun atau lebih (Pasal 32 ayat 1$)$.

\section{Macam-macam Perlindungan Kesejahteraan Anak}

Siapapun yang hidup di dunia ini, mempunyai hak yang sama untuk merasakan namanya suatu keadaan yang sejahtera. Semua manusia berhak merasakan apa itu kebahagiaan, kesehatan, maupun kualitas hidup yang bisa membuat kita menjadi lebih menikmati hidup. (Migley, James.1995. Social Development: The Developmental Perspective in Social Welfare. London: Sage Publications Ltd).

Dalam menjalankan kehidupannya, anak harus mendapat perlindungan, antara lain:

a. Hak Anak:

- Perlindungan anak adalah segala kegiatan untuk menjamin dan melindungi anak dan hakhaknya agar dapat hidup, tumbuh, berkembang, dan berpartisipasi, secara optimal sesuai dengan harkat dan martabat kemanusiaan, serta mendapat perlindungan dari kekerasan dan diskriminasi;

- Setiap anak berhak atas suatu nama sebagai identitas diri dan status kewarganegaraan;

- Setiap anak berhak untuk beribadah menurut agamanya, berpikir, dan berekspresi sesuai dengan tingkat kecerdasan dan usianya, dalam bimbingan orang tua;

- Setiap anak berhak untuk diasuh oleh orang tuanya sendiri, kecuali jika ada alasan dan/atau aturan hukum yang sah menunjukkan bahwa pemisahan itu adalah demi kepentingan terbaik bagi anak dan merupakan pertimbangan terakhir; 
- Setiap anak yang menjadi korban atau pelaku tindak pidana berhak mendapatkan bantuan hukum dan bantuan lainnya;

- Dan masih hak-hak lainnya yang sudah diatur dalam UU Republik Indonesia Nomor 23 Tahun 2002 Tentang Perlindungan Anak dan UU Republik Indonesia Nomer 3 Tahun 1997 disertai UU Republik Indonesia Nomer 11 Tahun 2012 Tentang Sistem Peradilan Anak.

\section{Situasi dan Kondisi Anak Yang Berhadapan Dengan Hukum}

Ruang sidang dengan petugas berseragam dan rumah tahanan mungkin akan menjadi mimpi buruk bagi setiap anak disepanjang hidupnya. Anak sekecil dan sedini itu harus memikul beban yang semestinya tidak ditanggung anak seusianya. Banyak pihak yang menilai bahwa proses hokum tersebut tidak mempertimbangkan aspek edukatif, konstruktif dan cenderung destruktif karena justru menimbulkan efek negatif bagi anak.

Dalam penanganan anak yang berkonflik dengan hokum ada 7 (tujuh) Pilar Peradilan Anak yaitu : Polisi, Advokat, Jaksa, Hakim, Petugas Bapas, Petugas Lapas dan Warga Masyarakat. Kita mengetahui Kepolisian (Penyidik) sebagai pintu gerbang penanganan perkara anak (korban, pelaku atau saksi) sering kali justru melakukan "kekerasan dan penganiayaan" pada saat menangkap dan memeriksa dalam proses pembuatan Berita Acara Pemeriksaan (BAP), juga ketika anak dalam tahanan kantor polisi.

Begitu juga ketika di Kejaksaan (JPU) belum mampu untuk memberikan pelayanan yang terbaik bagi anak yang berhadapan dengan hukum. Sering kali JPU cenderung mendukung BAP kepolisian untuk diajukan pada peradilan. Yang sebenarnya jaksa dapat mengambil tindakan pengabaian atau tidak meneruskan / melanjutkan suatu perkara anak ketahap selanjutnya atau memberikan keputusan dengan bentuk pengalihan dari proses hukum formal lebih lanjut. Hal ini dengan tujuan agar untuk meminimalkan anak-anak dari kerugian lebih lanjut akibat keberadaannya dalam system peradilan pidana. Hal yang hamper sama juga terjadi dalam proses peradilan, dimana anak-anak yang berhadapan dengan hokum pada dasarnya memiliki hak untuk didampingi oleh pengacara / advokat, didampingi petugas dari Bapas atau didampingi orang tua atau walinya. Tetapi dalam banyak kasus anak, pengacara/advokat, petugas Bapas, orang tua atau walinya sering kali tidak hadir. Bahkan kadang-kadang dalam persidangan anak tidak boleh didampingi pengacara/advokat atau petugas Bapas. Ketukan palu hakim lah paling menentukan atas nasib anak sehingga menjadi anak negara, dipenjara atau dikembalikan kepada orang tuanya. Secara umum penanganan kasus anak yang berkonflik dengan hukum masih memprihatinkan apakah disebabkan oleh ketidak pahaman aparat penegak hokum sehingga mengakibatkan hak-hak anak terabaikan begitu saja.

\section{Penutup}

Keberadaan Undang-undang tentang perlindungan terhadap anak di Indonesia sudah ada, terus diperbaharui sesuai dengan kebutuhan seiring dengan berkembangnya masalah yang terus ada. Akan tetapi, keberadaan Undang-undang tersebut tidak diikuti dengan sistem yang ada dipemerintahan kita. Pelayanan yang diberikan untuk kasus anak terkesan masih minim. Penegakan hukum, disertai dengan tindakan tegas terhadap kasus yang menimpa anak seharusnya bisa dilakukan agar anak-anak Indonesia tidak lagi menjadi korban, atau tersangka dalam kasus tindakan pidana.

Penyelenggaraan perlindungan terhadap seseorang, terutama anak yang berhadapan dengan hukum berdasarkan pada prinsip kemanusiaan dan keadilan. Sehingga setiap orang harus mendapatkan haknya atas perlindungan terhadap rasa aman serta terbebas dari penyiksaan atau perlakuan yang merendahkan derajat martabat manusia yang bertentangan dengan apa yang dicitacitakan dalam Pembukaan Undang-Undang Dasar Negara Republik Indonesia Tahun 1945 yaitu terciptanya kemanusiaan yang adil dan beradab. Untuk mencapai layanan perlindungan anak korban kekerasan dan anak yang berhadapan dengan hukum secara terpadu dan komperhensif diperlukan 
bentuk layanan secara terpadu dari berbagai lembaga terkait meliputi pelayanan medis, mediocolegal, psikososial, bantuan hukum, pendampingan, kemandirian ekonomi (pelatihan). Layanan tersebut dilakukan secara merata ke seluruh lapisan masyarakat sehingga setiap warga negara berhak memperoleh kesempatan yang sama untuk mendapatkan keamanan dan perlindungan secara hukum.

Secara prinsip, sasaran strategis penyelenggaraan perlindungan adalah menjaga keberlanjutan perlindungan melalui upaya layanan terpadu, komperhensif dan rumah aman dan nyaman yang kondusif untuk korban kekerasan. Sasaran strategis tersebut ditempuh melalui tahapan-tahapan yang saling terkait, baik perencanaan, perlindungan, layanan dan pembiayaan, pengawasan serta sanksi.

Ada tiga fenomena penting yang perlu dicermati dalam kaitan dengan penyelenggaraan perlindungan anak yang berhadapan dengan hukum. Pertama, adalah lemahnya perlindungan anak yang sedang berhadapan dengan hukum. Kedua, minimnya sarana dan prasarana didalam berlangsungnya proses anak yang berhadapan dengan hukum. Ketiga fenomena tersebut mengindikasikan bahwa penegakan dan perlindungan hukum, terutama perlindungan kepada anak masih sangat lemah dan perlunya peningkatan di sektor tersebut. Kekerasan yang dilakukan oleh faktor lingkungan akan berpengaruh kepada kepribadian anak itu sendiri. (Abraham Maslow, 1954). Anak adalah amanah dan karunia Tuhan Yang Maha Esa, dalam dirinya melekat harkat dan martabat sebagai manusia seutuhnya. Anak adalah generasi penerus cita-cita perjuangan bangsa yang memiliki peran strategis, dan mempunyai ciri dan sifat khusus yang diharapkan dapat menjamin kelangsungan eksistensi bangsa dan negara di masa depan. Anak perlu mendapat kesempatan seluas-luasnya untuk tumbuh dan berkembang secara optimal, baik secara fisik, mental,kognitif, spiritual maupun sosial. Karena sifatnya, maka tumbuh kembang anak harus dilakukan dalam lingkungan yang melindungi dari segala bahaya dalam bentuk pengasuhan yang optimal. Peran orang tua pun sangat dibutuhkan, apalagi jika lingkungan tempat tinggal serta tempat beraktifitas kurang mendukung untuk memberikan kenyamanan dan keamanan yang tidak memadai untuk mendukung kinerja sang anak.

\section{PUSTAKA}

Anna Volz, Advocacy Strategies Training Manual: General Comment No.10: Children's Rights in Juvenile Justice, Defence for Children International, 2009. Dalam Yayasan Pemantau Hak Anak, Anak yang Berhadapan dengan Hukum dalam Perspektif Hukum Hak Asasi Manusia Internasional, Internet, hal 1. Diakses pada 18 Desember 2014.

Badan Pusat Statistik,2000, Indikator Kesejahteraan Anak, Jakarta.

Badan Pusat Statistik, 2002, Indikator dan Profil Kesejahteraan dan Perlindungan Anak, Jakarta.

Departemen Kehakiman dan HAM, 1999, Undang-undang R.I. No.39 tahun 1999 tentang HAM, Jakarta.

Maslow, Abraham. 1954. Motivasi dan Kepribadian.

Migley, James.1995. Social Development: The Developmental Perspective in Social Welfare. London:Sage Publications Ltd.

Soetodjo, Wagiati, 2006. HukumPidanaAnak. Bandung, PT. Refika Aditama. Hal. 17.

\section{Lain-lain}

Undang-Undang Republik Indonesia Tentang Nomor 3 Tahun 1997 Tentang Pengadilan Anak Undang-Undang Republik Indonesia Tentang Nomor 23 Tahun 2002 Tentang Perlindungan Anak Undang-Undang Republik Indonesia Tentang Nomor 11 Tahun 2012 Tentang Sistem Pengadilan Anak 